\title{
Modelling the occupational exposure of workers to certain hazardous chemicals
}

\author{
Vlad Mihai Păsculescu ${ }^{1 *}$, Emilian Ghicioi ${ }^{1}$, Dragoş Păsculescu ${ }^{2}$, and Mircea Suciu $^{3}$ \\ ${ }^{1}$ National Institute for Research and Development in Mine Safety and Protection to Explosion - \\ INSEMEX, 32-34 G-ral Vasile Milea street, 332047, Petrosani, Hunedoara county, Romania \\ ${ }^{2}$ University of Petroşani, Faculty of Mechanical and Electrical Engineering, Department of \\ Automation, Computers, Electrical Engineering and Energetics, 20 Universităţii street, 332006, \\ Petrosani, Hunedoara county, Romania \\ 3"'Constantin Brancusi" University of Targu Jiu, Republicii, 210135, Targu-Jiu, Gorj county, \\ Romania
}

\begin{abstract}
Hazardous substances are considered to be liquids, gases or solids which are of risk for the health and safety of workers and they may be found in almost all workplaces, including in SME's. Hazardous substances include chemical agents, but also biological ones, such as bacteria, viruses, mould etc. Most chemicals used in the industry present risk for the workers, depending on their physico-chemical properties. Directive 2012/18/EU is the legal act which regulates the chemical substances field within the Member States, regulation dealing with the control of hazards involving dangerous substances which may lead to major accidents. In Romania, Law 59 dated April 2016 on controlling the hazard of major accidents caused by hazardous substances evaluates "hazardous chemicals", describing the risk for people and regulating concentrations of such substances. By using the commercially available Phast consequence modelling package, within this study were modelled leaks of several chemical substances used in the industry, in order to estimate their hazardous influence extent. The current article is a significant work on modelling of discharge and atmospheric dispersion of hazardous substances using state-of-the-art consequence modelling software. Emergency Response Planning Guidelines (ERPG) are used as reference exposure levels within the present study. Output data of computational modelling are significantly influenced by input parameters. In this regard, the effects of the latter for ensuring robustness of the simulation and for identifying improvements have proven to be necessary.
\end{abstract}

\section{Introduction}

In the industrial field, there are used many chemicals which present various risks depending on and whose physical-chemical properties may change drastically with

\footnotetext{
* Corresponding author: vlad.pasculescu@insemex.ro
} 
concentration $[1,2,3]$. Such chemicals can be used in industrial processes as solutions with water.

In Romania, Law 59 dated April 2016 on controlling the hazard of major accidents caused by hazardous substances evaluates "hazardous chemicals", describing the risk for people and regulating concentrations of such substances [4, 5]. In order to be prepared for possible accidents, it is a common practice nowadays to develop computational analyses regarding the potential damage extent in case of accidents [6-10].

Chemical substances used in the manufacturing sector must be controlled at national level as there are risks associated with chemical substances in the raw materials themselves [11-15]. The differences in regulated concentration of chemical substances between countries suggest a serious issue. Countries with low chemical regulatory concentrations may be over-regulated. On the other hand, countries with high levels of chemical regulations can not manage low concentration chemicals, so chemical accidents can occur at low concentrations.

This study used PHAST 8.22. modelling program to measure values according to the toxic concentration Emergency Response Planning Guideline (ERPG-1, ERPG-2 and ERPG-3), in case of unexpected leaks of a tank located within an industrial facility and which contains such chemicals $[15,16,17]$.

\section{Chemical substances involved}

Within the study are selected chemical substances that are used in many industries, that have almost identical physical and chemical properties and which are being used in various industrial processes: hydrogen chloride, hydrogen fluoride, and hydrogen peroxide, for which the basic chemical and physical properties are presented in Table 1.

Table 1. Physical/chemical properties of analysed substances

\begin{tabular}{|c|c|c|c|}
\hline Property & Hydrogen chloride & Hydrogen fluoride & Hydrogen peroxide \\
\hline $\begin{array}{l}\text { Chemical } \\
\text { Abstracts Service } \\
\text { (CAS) number }\end{array}$ & $7647-01-0$ & $7644-39-3$ & $7722-84-1$ \\
\hline Formula & $\mathrm{HCl}$ & $\mathrm{HF}$ & $\mathrm{H}_{2} \mathrm{O}_{2}$ \\
\hline Molecular weight & 36.4606 & 20.0063 & 34.0147 \\
\hline $\begin{array}{ll}\begin{array}{l}\text { Melting point } \\
(\operatorname{deg} C)\end{array} & \\
\end{array}$ & -114.18 & -83.36 & -0.425 \\
\hline $\begin{array}{l}\text { Normal boiling } \\
\text { point (deg } \mathrm{C})\end{array}$ & -85 & 19.52 & 150.2 \\
\hline $\begin{array}{l}\text { Vapour density } \\
(\mathrm{g} / \mathrm{L})\end{array}$ & $1.268(25 \mathrm{deg} c)$ & $0.92(0 \operatorname{deg} \mathrm{C})$ & $1.17(25 \operatorname{deg} C)$ \\
\hline $\begin{array}{l}\text { Vapour pressure } \\
(\mathrm{mmHg})\end{array}$ & $31,652(20 \operatorname{deg} C)$ & $917(25 \operatorname{deg} C)$ & $1.97(25 \operatorname{deg} C)$ \\
\hline Odour & Foul smelling & Strong, irritating & No odour or weak odour \\
\hline Colour & Colourless liquid/gas & Colourless liquid/gas & Colourless liquid \\
\hline Purpose & $\begin{array}{l}\text { Production, vinyl } \\
\text { chloride polymer }\end{array}$ & $\begin{array}{l}\text { Manufacturing disinfectants, } \\
\text { refrigerants, cleaners etc. }\end{array}$ & $\begin{array}{c}\text { Disinfectant, bleach, } \\
\text { detergent, oxidizing agent }\end{array}$ \\
\hline
\end{tabular}

\subsection{Concentration}

Concentration level recommendations and guidelines are used for determining whether individuals in an emergency response scenario will be impacted by their proximity to certain hazardous chemicals. Emergency Response Planning Guidelines - ERPG are the best known and most commonly measures used worldwide [18]. 
For the substances to which they are applicable, these criteria use a three-category system to rate exposure values; individual ratings are unique to each chemical dose, but the three categories are identical.

A compound may have up to three ERPG levels, each leading to a different level of health effects. The three ERPG tiers are defined as follows: a level 1 value indicates temporary damage, a level 2 value indicates failure or serious health effects, and a level 3 value indicates life-threatening effects.

- ERPG-1 specifies the total airborne level at which almost all individuals could be exposed for up to one hour without experiencing more than mild, intermittent adverse health effects or without perceiving a clearly defined adverse odor.

- ERPG-2 specifies the total airborne levels to which individuals may be exposed for up to one hour without permanent or other serious health effects or symptoms.

- ERPG-3 is the peak airborne concentration at which almost all people could be exposed for up to 1 hour without life-threatening health effects [18].

\section{Accident modelling}

Based on each material in the modelling, the hazardous distances downwind for two leaks differing in diameter are determined, ERPG-1, 2 and 3 levels of toxic concentrations being set as endpoints, taking into account that all substances were released under the same operating conditions. Saturation vapour pressure varies for each concentration, given both leakage exist under the same conditions; concentration and saturation vapour pressure can therefore be adjusted in a simulation system. Phast software uses for modelling the Gaussian atmospheric diffusion which is used widely for assessing the environmental impact in case of accidental releases of hazardous substances. In the paper, for modelling purposes, there has been assumed a constant leak rate and also that no chemical reaction occurs during the leak. This characteristic is consistent with the theory of modelling assuming that due to the vapour pressure, the chemical forms a pool and continually evaporates and diffuses. The release direction has been assumed to be horizontal.

\subsection{Input parameters}

\subsubsection{Weather}

- Ambient temperature: $20^{\circ} \mathrm{C}$

- Atmospheric humidity: $70 \%$

- Wind speed: $1.5 \mathrm{~m} /$

- Pasquil stability class: D - Neutral conditions

- Solar Radiation: $0.5 \mathrm{~kW} / \mathrm{m}^{2}$

\subsubsection{Endpoint concentration}

The present study calculated the hazardous distances downwind for each chemical substance by setting the ERPG-1, 2 and 3 endpoint concentrations as the concentrations of interest, as presented in Table 2:

Table 2. Endpoint concentrations

\begin{tabular}{|c|c|c|c|}
\hline ERPG Levels & Hydrogen chloride & Hydrogen fluoride & Hydrogen peroxide \\
\hline ERPG-1 & $3 \mathrm{ppm}$ & $2 \mathrm{ppm}$ & $10 \mathrm{ppm}$ \\
\hline ERPG-2 & $20 \mathrm{ppm}$ & $20 \mathrm{ppm}$ & $50 \mathrm{ppm}$ \\
\hline ERPG-3 & $150 \mathrm{ppm}$ & $50 \mathrm{ppm}$ & $100 \mathrm{ppm}$ \\
\hline
\end{tabular}




\subsubsection{Scenario}

The three chemicals in liquid form involved where assumed to leak from a tank, through a $10 \mathrm{~mm}$ and a $100 \mathrm{~mm}$ leak, at atmospheric temperature and pressure. The leaking tank has been assumed to contain $3000 \mathrm{~kg}$ of chemical substance.

For measuring the ERPG-2 level concentrations have been selected three distances of interest: $50 \mathrm{~m}, 100 \mathrm{~m}$, and $250 \mathrm{~m}$.

\subsection{Results obtained}

The distances downwind to the concentrations of interest calculated under the same conditions for each of the three chemical substances are presented in Table 3. For the three distances of interest, results of concentrations are presented in Table 4.

Table 3. Distance downwind to defined concentrations

\begin{tabular}{|c|c|c|c|}
\hline $\begin{array}{l}\text { Chemical } \\
\text { substance }\end{array}$ & Scenario & Concentration of interest & $\begin{array}{l}\text { Distance downwind to } \\
\text { concentration of interest } \\
{[\mathrm{m}]}\end{array}$ \\
\hline \multirow{2}{*}{$\begin{array}{l}\text { Hydrogen } \\
\text { chloride }\end{array}$} & $10 \mathrm{~mm}$ leak & \multirow{2}{*}{$20 \mathrm{ppm}$} & 475.042 \\
\hline & $100 \mathrm{~mm}$ leak & & 4207.76 \\
\hline \multirow{2}{*}{ Hydrogen fluoride } & $10 \mathrm{~mm}$ leak & \multirow{2}{*}{20 ppm } & 580.597 \\
\hline & $100 \mathrm{~mm}$ leak & & 2440.58 \\
\hline \multirow{2}{*}{$\begin{array}{l}\text { Hydrogen } \\
\text { peroxide }\end{array}$} & $10 \mathrm{~mm}$ leak & \multirow{2}{*}{$50 \mathrm{ppm}$} & 30.6874 \\
\hline & $100 \mathrm{~mm}$ leak & & 26.8138 \\
\hline
\end{tabular}

Table 4. Concentrations at defined distances of interest downwind

\begin{tabular}{|c|c|c|c|}
\hline $\begin{array}{r}\text { Chemical } \\
\text { substance }\end{array}$ & Scenario & Distance of Interest & $\begin{array}{c}\text { Concentration at distance } \\
\text { of interest [ppm] }\end{array}$ \\
\hline $\mathrm{HCL}$ & \multirow{3}{*}{$10 \mathrm{~mm}$ leak } & \multirow{6}{*}{$50 \mathrm{~m}$} & 3023.89 \\
\hline $\mathrm{HF}$ & & & 2902.45 \\
\hline $\mathrm{H} 2 \mathrm{O} 2$ & & & 62.521 \\
\hline $\mathrm{HCL}$ & \multirow{3}{*}{$100 \mathrm{~mm}$ leak } & & 166176 \\
\hline HF & & & 15491.3 \\
\hline $\mathrm{H} 2 \mathrm{O} 2$ & & & 65.9066 \\
\hline $\mathrm{HCL}$ & \multirow{3}{*}{$10 \mathrm{~mm}$ leak } & \multirow{6}{*}{$100 \mathrm{~m}$} & 665.973 \\
\hline $\mathrm{HF}$ & & & 960.301 \\
\hline $\mathrm{H} 2 \mathrm{O} 2$ & & & 18.3037 \\
\hline $\mathrm{HCL}$ & \multirow{3}{*}{$100 \mathrm{~mm}$ leak } & & 43634.7 \\
\hline $\mathrm{HF}$ & & & 170703 \\
\hline $\mathrm{H} 2 \mathrm{O} 2$ & & & 30.4744 \\
\hline $\mathrm{HCL}$ & \multirow{3}{*}{$10 \mathrm{~mm}$ leak } & \multirow{6}{*}{$250 \mathrm{~m}$} & 155.183 \\
\hline $\mathrm{HF}$ & & & 232.439 \\
\hline $\mathrm{H} 2 \mathrm{O} 2$ & & & 0 \\
\hline $\mathrm{HCL}$ & \multirow{3}{*}{$100 \mathrm{~mm}$ leak } & & 6414.03 \\
\hline $\mathrm{HF}$ & & & 27373.5 \\
\hline $\mathrm{H} 2 \mathrm{O} 2$ & & & 0 \\
\hline
\end{tabular}

Table 5. Distance downwind to ERPG Levels

\begin{tabular}{|c|c|c|c|}
\hline $\begin{array}{c}\text { Chemical } \\
\text { substance / } \\
\text { Scenario }\end{array}$ & $\begin{array}{c}\text { Distance } \\
\text { downwind to } \\
\text { ERPG-1 } \\
\text { [m] }\end{array}$ & $\begin{array}{c}\text { Distance } \\
\text { downwind to } \\
\text { ERPG-2 } \\
\text { [m] }\end{array}$ & $\begin{array}{c}\text { Distance } \\
\text { downwind to } \\
\text { ERPG-3 } \\
\text { [m] }\end{array}$ \\
\hline $\mathrm{HCl} \mathrm{10} \mathrm{mm} \mathrm{leak}$ & 1534 & 475.474 & 131.778 \\
\hline $\mathrm{HCl} \mathrm{100} \mathrm{mm} \mathrm{leak}$ & 10168.9 & 4281.58 & 1749.16 \\
\hline $\mathrm{HF} 10 \mathrm{~mm}$ leak & 2189.25 & 581.483 & 338.717 \\
\hline $\mathrm{HF} \mathrm{100} \mathrm{mm} \mathrm{leak}$ & 8869.76 & 2463.66 & 1562 \\
\hline $\mathrm{H}_{2} \mathrm{O}_{2} 10 \mathrm{~mm}$ leak & 77.8441 & 30.7122 & 21.2185 \\
\hline $\mathrm{H}_{2} \mathrm{O}_{2} 100 \mathrm{~mm}$ leak & 105.419 & 26.8337 & 19.5642 \\
\hline
\end{tabular}



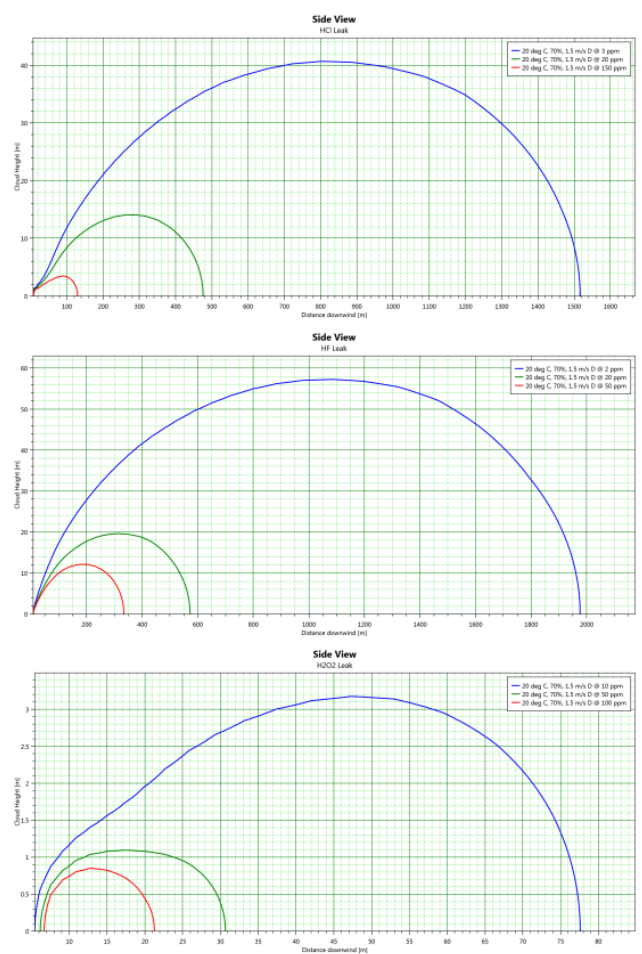

a) $10 \mathrm{~mm}$ leak

Fig. 1. Toxic gas cloud - Side view

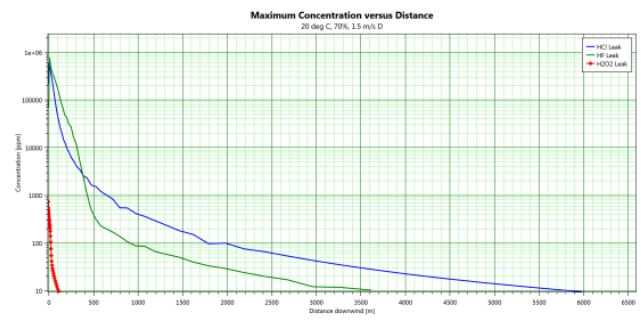

a) $10 \mathrm{~mm}$ leak

Fig. 2. Maxim Concentration vs Distance

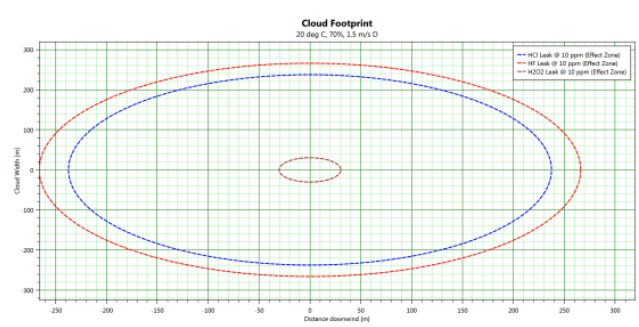

a) $10 \mathrm{~mm}$ leak
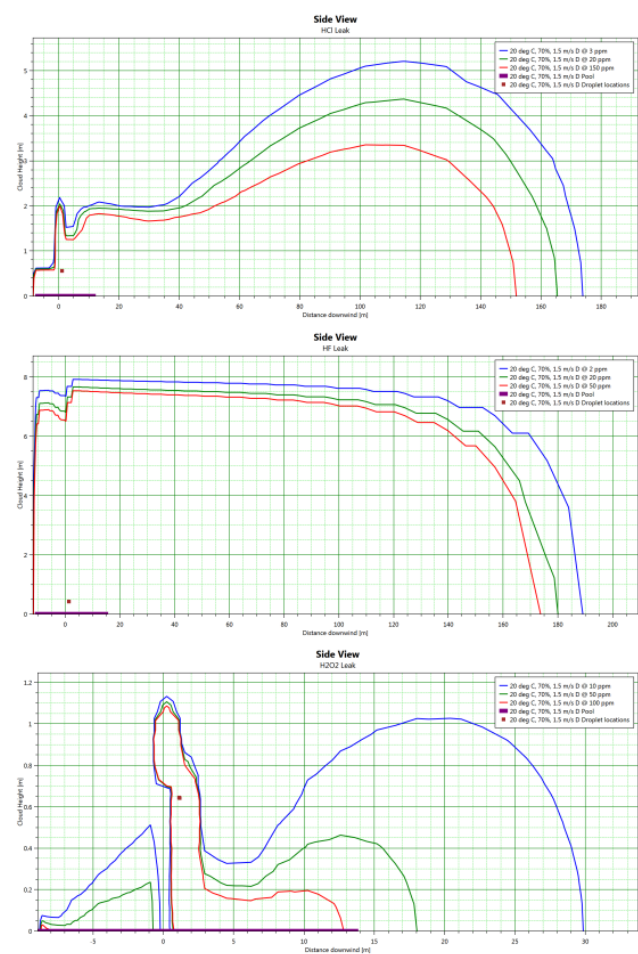

b) $100 \mathrm{~mm}$ leak

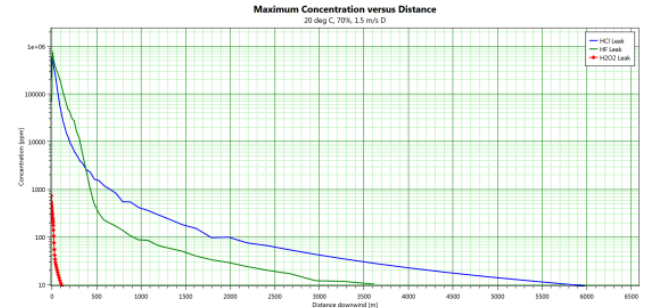

b) $100 \mathrm{~mm}$ leak

Fig. 3. Dispersion Cloud maximum footprint for $10 \mathrm{ppm}$ effect zone 
Figures 1, 2 and 3 present the dispersed cloud and maximum concentrations of hydrogen chloride, hydrogen fluoride and hydrogen peroxide with the distance downwind from the possible leak.

\section{Conclusions and final remarks}

Modelling programs existing nowadays are widely used for taking precautions and preventive measures against chemical accidents which may have unwanted consequences upon the workers and surrounding environment. However, the results of the predicted models may be different from the ones which can be generated by such accidents, thus the limitation of the computational modelling. Anyway, if additional results from real-life experiments cannot be obtained for comparing the values obtained by modelling, such preventive works are trustful since the mathematical models which are implement within commercially available software are validated.

The paper presented the distances for representative ERPG-2 concentrations, distances obtained for representative scenarios of chemical accidents involved by widely used chemicals: hydrogen chloride, hydrogen fluoride and hydrogen peroxide. Graphs presented in the paper can be used for emergency plans residing in the fast evacuation of workers in case of accidental releases of one of the three substances analysed.

This paper was developed within the Nucleu-Programme, carried out with the support of Romanian Ministry of Research and Innovation, project no. PN-19-21-02-01, project title: Techniques and solutions for developing the scientific and technical competences for prevention and protection to explosions (in Romanian: Tehnici si solutii pentru dezvoltarea competentelor stiintifice si tehnice de prevenire si protectie la explozie).

\section{References}

1. M. Toderas, C. Danciu, M., Proceedings of the 18th International Multidisciplinary Scientific GeoConference SGEM 2018, 18 (1.3), 207-214, (2018)

2. D. Codruta, A. P. Paun, R. I. Moraru, Quality - Access to Success, 19 (162), 155-160, (2018)

3. G. B. Babut, R. I. Moraru, Quality - Access to Success, 19 (166), 133-144, (2018)

4. Law 59/2016/Romania, (2016)

5. Norms on the application of Law 59/2016/Romania, (2017)

6. M. Leba. A. Ionica, R. Dobra, V. M. Pasculescu, Environ Eng Manag J, 13 (6), 1365-1370, (2014)

7. V. M. Pasculescu, N. I. Vlasin, D. Florea, M.C. Suvar, Quality - Access to Success, 18, 97-102, (2017)

8. V. M. Pasculescu, S. M. Radu, E. Ghicioi, D. Pasculescu, T. Niculescu, Proceedings of the 14th International Multidisciplinary Scientific GeoConference SGEM 2014, 1 (2), 43-50, (2014)

9. V. M. Pasculescu, N. I. Vlasin, M. C. Suvar, C. Lupu, Environ Eng Manag J, 16 (6), 1323-1330, (2017)

10. M. Suvar, D. Cioclea, I. Gherghe, V. Pasculescu, Environ Eng Manag J, 11 (7), 1235-1239, (2012)

11. V. M. Pasculescu, N. I. Vlasin, E. Ghicioi, G. D. Florea, M.C. Suvar, Environ Eng Manag J, 18 (4), 889-900, (2019)

12. D. Pasculescu, L. Pana, V. M. Pasculescu, F. Deliu, Mining of Mineral Deposits, 13 (2), 1-16, (2019)

13. G. D. Vasilescu, E. Ghicioi, S. Simion, V. M. Pasculescu, Appl Mech Mater, 430, 276-280, (2013)

14. G. Buica, A. E. Antonov, C. Beiu, I. Iorga, Environ Eng Manag J, 11 (7), 1247-1255, (2012)

15. G. D. Florea, N. I. Vlasin, Z. Vass, B. A. Simon, L. I. Tuhut, Conference Proceedings of International Multidisciplinary Symposium "Universitaria SIMPRO 2018" - 8th Edition, 145$150,(2018)$ 
16. Phast Software features. Available on https://www.dnvgl.com/services/process-hazard-analysissoftware-phast-1675

17. V. M. Pasculescu, E. Ghicioi, M. S. Morar, D. Pasculescu, M. C. Suvar, Quality - Access to Success, 20, 25-30, (2019)

18. Emergency Response Planning Guidelines (ERPG) and Workplace Environmental Exposure Level (WEEL) Handbook, AIHA Guideline Foundation, (2017) 